\title{
Morphological characterisation of Paranoplocephala bairdi (Schad, 1954) (Cestoda: Anoplocephalidae) in heather voles Phenacomys spp. and tree voles Arborimus spp., and related species in voles and lemmings (Muridae: Arvicolinae)
}

\author{
Voitto Haukisalmi ${ }^{1}$, Robert L. Rausch $^{2}$ and Heikki Henttonen ${ }^{1}$ \\ ${ }^{1}$ Finnish Forest Research Institute, Vantaa Research Centre, P.O. Box 18, FIN-01301 Vantaa, Finland; \\ ${ }^{2}$ University of Washington School of Medicine, Department of Comparative Medicine, Box 357190, Seattle, WA 98195-7190, \\ USA
}

Key words: Paranoplocephala bairdi, Anoplocephalidae, Cestoda, voles, Phenacomys, Arborimus

\begin{abstract}
The taxonomical status of Paranoplocephala bairdi (Schad, 1954)-like cestodes (Anoplocephalidae) in heather voles Phenacomys spp. and tree voles Arborimus spp. (Muridae: Arvicolinae) and their discrimination from five related species of Paranoplocephala is assessed using uni- and multivariate morphometrics. The analyses support the independent status and conspecificity of specimens from Phenacomys spp. and Arborimus spp., and P. bairdi is therefore suggested to be a host-specialist species of heather and tree voles with a wide geographical distribution in North America. A redescription is presented for $P$. bairdi.
\end{abstract}

Heather voles (Phenacomys Merriam) and tree voles (Arborimus Taylor) represent an assemblage of closely related Nearctic species of arvicoline rodents; see Musser and Carleton (1993), Wilson and Ruff (1999) and Bellinger et al. (2005) for the taxonomy and geographical distribution of heather and tree voles. Heather voles and tree voles occur either in low numbers and/or have a specialised (arboreal) life-style (Verts and Carraway 1998, Wilson and Ruff 1999), which explains the scarcity of parasitological research performed on them. So far, 3-4 species of anoplocephalid cestodes (below) and two species of heligmosomid nematodes (DuretteDesset et al. 1972, Rausch and Rausch 1973) have been reported from Phenacomys, but there are no published records of helminths of Arborimus, except for the finding of Andrya sp. in A. pomo (reported as "Phenacomys longicaudus" by Voge 1955). Data on helminth parasitism in Arborimus spp. would be particularly interesting, since these species are presently listed as endangered or threatened due to the decline and fragmentation of their preferred habitats (old-growth forests; e.g. Verts and Carraway 1998), and obtaining helminth material in future may be uncertain.

Andrya bairdi Schad, 1954 (Anoplocephalidae) was described by Schad (1954) from Phenacomys ungava from Quebec, Canada [the host species of P. bairdi was erroneously reported as Microtus chrotorrhinus (Miller); see Peterson 1962]. Andrya bairdi has subsequently been included within the genus Paranoplocephala Lühe, 1910, as emended by Rausch (1976), along with other Andrya-like cestodes parasitizing arvicoline rodents (voles and lemmings) (e.g. Tenora et al.
1986, Haukisalmi and Henttonen 2000). It has been recently shown by a molecular phylogenetic analysis that Andrya and Paranoplocephala represent two independent genera, and that all species from arvicoline rodents belong to the latter genus (Wickström et al. 2005).

It should be emphasised that there exist no records of this species after the original description. Haukisalmi and Henttonen (2000) redescribed $P$. bairdi briefly from a single paratype specimen and compared it with $P$. fellmani, a parasite of Lemmus spp., but the morphological features that distinguish $P$. bairdi from the other related species have not been defined. Thus, although $P$. bairdi has consistently been recognized as a valid species, the morphological variation, host range and geographical distribution of this species remain poorly known.

We describe here the morphological variation within $P$. bairdi-like cestodes, including the type specimens from $P$. ungava, and compare them with five morphologically related species of Paranoplocephala from voles, lemmings and squirrels using uni- and multivariate morphometrics. Paranoplocephala bairdi is redescribed according to the material from Phenacomys spp. and Arborimus spp.

\section{MATERIALS AND METHODS}

Cestodes. The Paranoplocephala material from Phenacomys and Arborimus consists of 18 specimens, including the holotype and two paratypes of P. bairdi (Table 1). These specimens are compared morphometrically with $P$. arctica (Rausch, 1952) sensu Haukisalmi et al. 2001, P. fellmani 
Haukisalmi et Henttonen, 2001, P. nordenskioeldi Haukisalmi, Wickström, Hantula et Henttonen, 2001, P. primordialis (Douthitt, 1915) and P. serrata Haukisalmi et Henttonen, 2000. They resemble $P$. bairdi in having unilateral or infrequently alternating genital pores, small scolex, long and slender neck, long vagina relative to the length of the cirrus sac and basically similar distribution of testes (see Haukisalmi et al. 2002 for main morphological features of Paranoplocephala spp. in Holarctic rodents). These five species have either a Nearctic ( $P$. arctica, P. primordialis) or a wide Holarctic distribution. A sample of each of these species was measured for the present morphometric analysis, and therefore the measurements in Tables 3 and 4 do not exactly correspond to those in the original descriptions or later redescriptions.

Cestodes were fixed in $70 \%$ ethanol, $10 \%$ formalin or Bouin's fixative, stained usually with Semichon's acetic carmine or Mayer's haemalum and mounted in Canada balsam.

Representative specimens of $P$. bairdi from each host species have been deposited in the United States National Parasite Collection, Beltsville, Maryland (USNPC; Table 1).

Morphometrics. When possible, 19 absolute and 2 relative measurements were recorded from each individual (Tables 3 and 4). Since we have earlier shown that replicate measurements are not necessary for assessing interspecific morphometric differences within Paranoplocephala (Haukisalmi and Henttonen 2003, Haukisalmi et al. 2004), organ dimensions were calculated from a single representative mature proglottis from each individual. However, replicate measurements were recorded for the diameter of suckers (usually four measurements per individual) and length of eggs (5-10 measurements per individual). For replicate measurements, the median value was used in the statistical analysis.

The scolex, neck and mature proglottides were drawn on paper with the aid of camera lucida, and various organs were counted and measured from these drawings using a calibrated ruler. Neck length was measured from the posterior margin of suckers to the beginning of visible segmentation. The poral distance of vitellarium (PV) was measured from the midpoint of vitellarium to the poral margin of the proglottis, and the distance between vitellarium and ovary (DO) was measured as the distance between the midpoints of these glands. The distribution of testes was characterized by three absolute variables (TD, PTN and ATN). TD is the transverse width of the testicular field, PTN (number of poral testes) refers to testes situated porally to the midline of the proglottis, and ATN (number of antiporal testes) to those situated antiporally to the ventral osmoregulatory canal. Cirrus sac was measured only if the cirrus was fully invaginated. Maximum length of cirrus sac (CSM) and seminal receptacle (SRM) were recorded from postmature proglottides.

In addition to the absolute measurements, we calculated two relative measurements, which are known as potentially important in the discrimination of anoplocephaline cestodes, i.e. the length/width ratio of mature proglottides and the index of asymmetry, quantifying the asymmetrical position of vitellarium. The latter was calculated as a ratio between the poral distance of vitellarium (measured from the midpoint of vitellarium to the poral margin of the proglottis) and the width of the corresponding proglottis.
Comparisons of absolute and relative measurements between different cestode species were performed using parametric one-way analysis of variance. If this test indicated significant differences $(p<0.05)$, Tukey's HSD-test was used to evaluate the pairwise differences between $P$. bairdi and each of the other species (Tables 3 and 4).

Since many of the morphometric variables were found to be strongly correlated with each other, we performed a principal component analysis (PCA) on 13 absolute organ measurements (Table 3). The idea of PCA is to extract a smaller set of new, uncorrelated variables (principal components) from the original, correlated variables. The principal components, which often reflect particular morphometric traits, can then be used in the subsequent statistical comparisons. The external dimensions and egg length (Table 4) were not included in the PCA because of several missing values.

We also performed a discriminant analysis for the six Paranoplocephala species using again the 13 absolute organ dimensions (Table 3). However, these results should be interpreted cautiously due to the frequent correlations between morphometric variables. The canonical discriminant functions were calculated using all variables simultaneously. Crossvalidation (jack-knifing) was used to evaluate the success of the discriminant functions to correctly classify the specimens under study, i.e. each specimen was classified by the discriminant functions derived from all specimens other than that specimen. No detailed results are shown for the principal component and discriminant analyses.

To improve fit to the normal distribution, $\arcsin \sqrt{ } \mathrm{x}$-transformation was performed on relative measurements (ratios). Statistical analyses were performed with SPSS for Windows ${ }^{\circledR}$ 10.0.05 (standard version).

\section{RESULTS}

Since we could not find consistent morphological differences between the type material of $P$. bairdi (host $P$. ungava) and the specimens from the other Phenacomys and Arborimus species, they are all classified here as $P$. bairdi (see Discussion).

\section{Univariate comparisons between Paranoplocephala bairdi and related species}

Each of the species compared here with P. bairdi differed significantly for 7-13 morphometric variables (total number of variables 21), $P$. primordialis being particularly distinct from $P$. bairdi in this respect (Tables 3 and 4). Each species also showed 2-5 characters that were nearly or completely non-overlapping with those of $P$. bairdi. Thus, univariate comparisons support the distinctiveness and independent status of $P$. bairdi among the morphologically related species of Paranoplocephala. The non-overlapping features in particular provide a reliable means of discriminating $P$. bairdi from the five related species; these are listed below.

Paranoplocephala arctica can be distinguished from $P$. bairdi according to the total number of testes and number of poral testes (lower in P.b.), distance between 

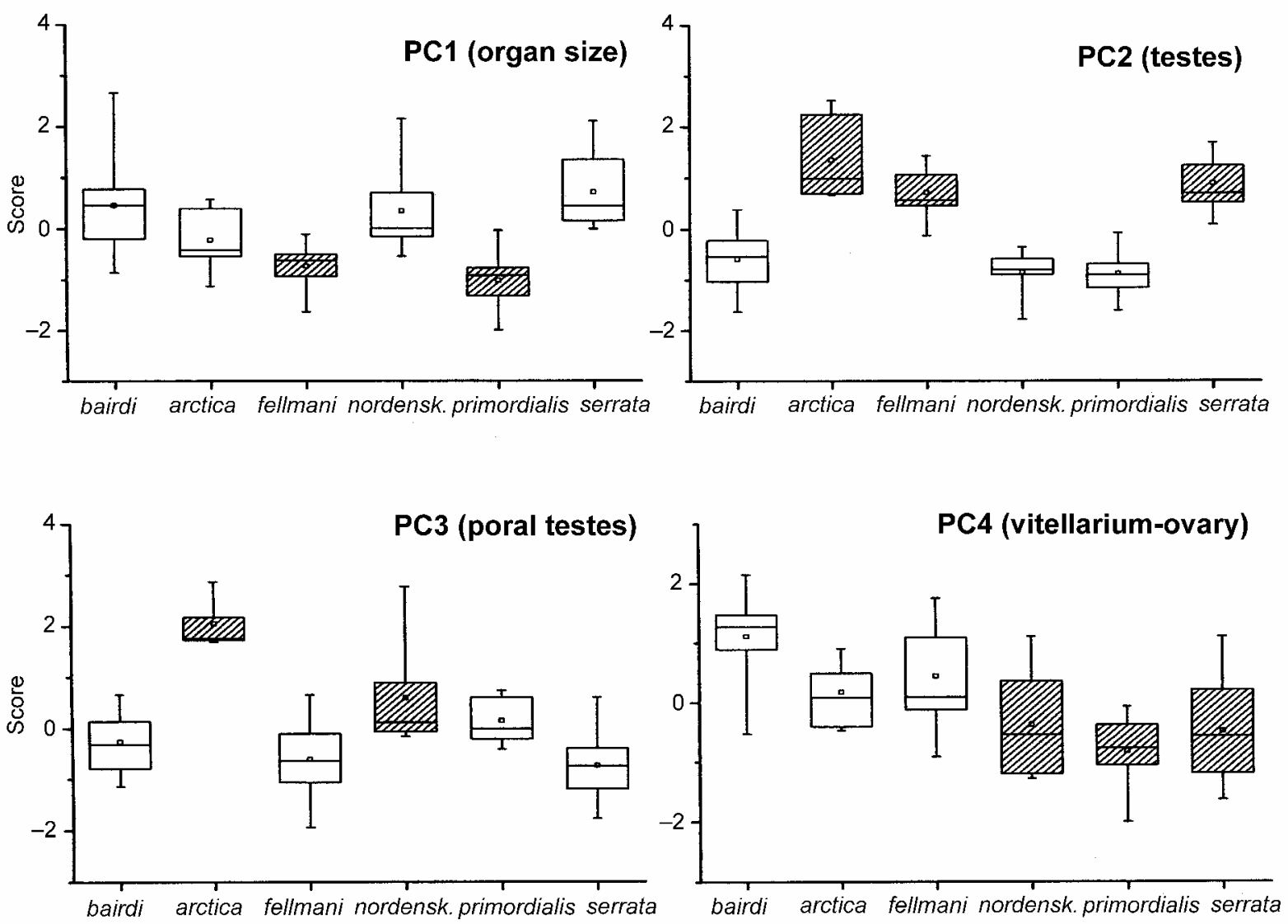

Fig. 1. Comparison of principal component (PC) scores between Paranoplocephala bairdi and other species. The graphs show the range (whiskers), lower and upper quartiles (box), median (transverse line within the box) and mean (small square within the box) of scores for each PC. Species differing significantly from P. bairdi are indicated by a shaded box. See text (Results) for interpretation of PCs.

the ovary and vitellarium (higher in P.b.) and egg length (much lower in P.b.). Paranoplocephala fellmani differs from $P$. bairdi by the width of the longitudinal ventral canals (higher in P.b.), dimensions of the seminal receptacle (higher in P.b.) and size of the scolex and suckers (smaller in P.b.). Paranoplocephala nordenskioeldi differs from $P$. bairdi by its larger scolex, suckers and eggs. Paranoplocephala primordialis also has larger scolex and suckers than $P$. bairdi, and it can additionally be distinguished from $P$. bairdi by the distance between the ovary and vitellarium (higher in P.b.). Paranoplocephala serrata has wider strobila and much larger eggs than $P$. bairdi.

\section{Multivariate morphometrics}

The PCA extracted four principal components (PCs) with Eigenvalues exceeding 1, each of them representing a statistically independent morphometric trait. PC1, accounting for $42 \%$ of the total variance, reflects the general size of various organs, including the width of the testicular field and poral distance of vitellarium. PC2 $(18 \%)$ combines two related features, the total number of testes and the number of antiporal testes. PC3
(11\%) and PC4 $(8 \%)$ are primarily measures of two individual traits, the number of poral testes and the distance between vitellarium and ovary, respectively.

According to $\mathrm{PC} 1, P$. bairdi has significantly larger organs (and other correlated features) than $P$. primordialis and P. fellmani (Fig. 1). Additionally, PC2 separates $P$. bairdi from $P$. fellmani, $P$. serrata and $P$. arctica, and PC3 from $P$. nordenskioeldi and $P$. arctica, indicating that there are significant differences in the number and distribution of testes between $P$. bairdi and the other species. Finally, PC4 further supports the observation that $P$. bairdi differs from most of the other species by its higher distance between vitellarium of ovary (cf. Table 3 ).

The overall classification success of the discriminant analysis, i.e. the proportion of all specimens assigned to the correct species, was $85.1 \%$. The classification success for different species varied from $60 \%$ (P. nordenskioeldi) to $100 \%$ (P. arctica and $P$. fellmani). Three of the 14 specimens of $P$. bairdi were misclassified as $P$. nordenskioeldi and $P$. serrata, giving a classification success of $78.6 \%$ for $P$. bairdi. Thus, the classification phase of the discriminant analysis shows relatively 

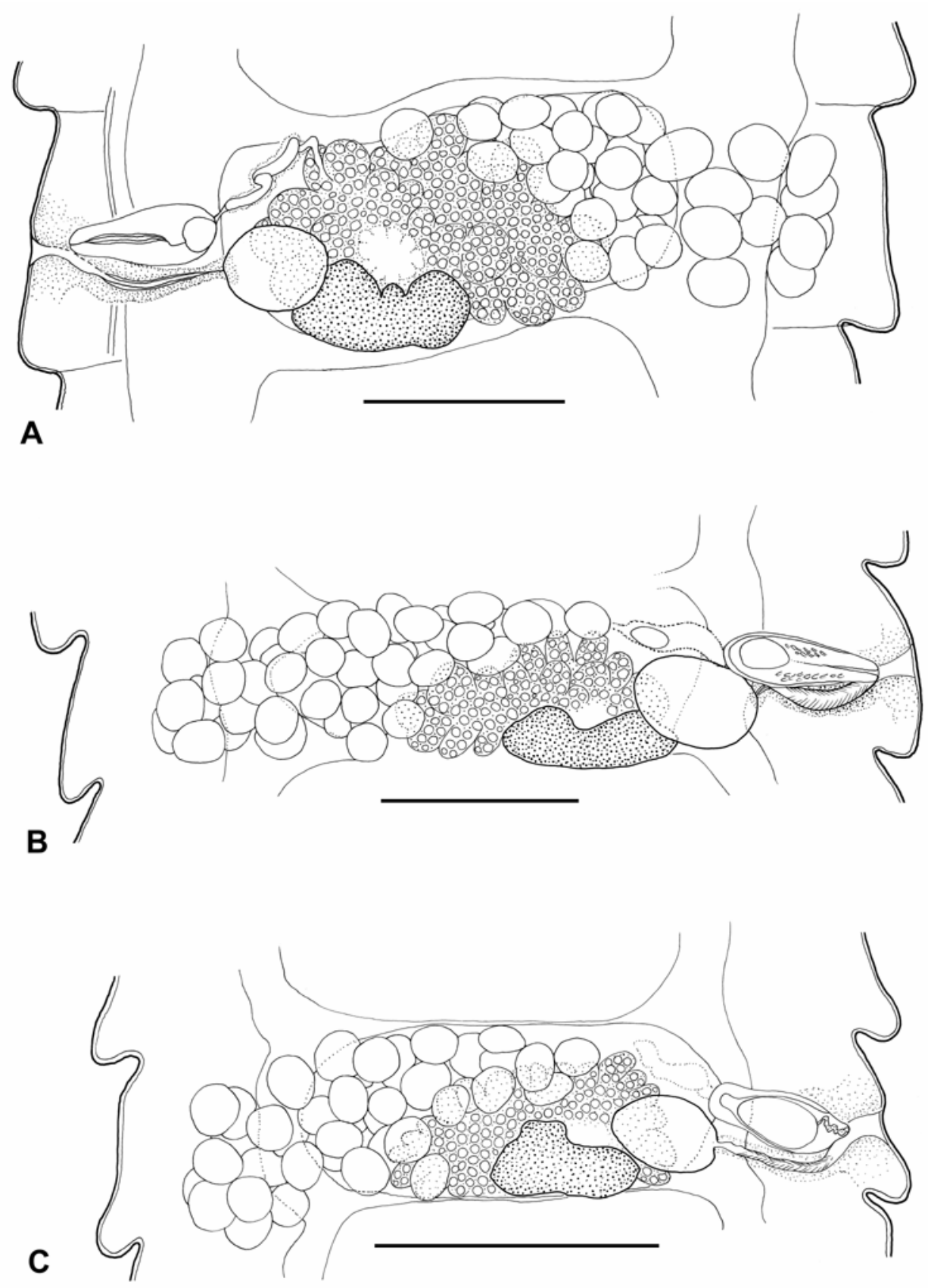

Fig. 2 A-C. Mature proglottides of Paranoplocephala bairdi from Phenacomys ungava (A - holotype), P. intermedius (B) and Arborimus albipes $(\mathbf{C})$. Scale bars $=0.30 \mathrm{~mm}$.

successful separation among the six species with partial morphometric overlap and occasional misclassifications between $P$. bairdi, $P$. nordenskioeldi and $P$. serrata.

Paranoplocephala bairdi (Schad, 1954)

Syn. Andrya bairdi Schad, 1954

The following redescription is based on 18 specimens from Phenacomys spp. and Arborimus spp. (Table 1). All measurements are in $\mathrm{mm}$.
Description (Figs. 2-4, Tables 2-4). Fully developed strobila long (up to 243), relatively thin. Maximum width attained in pregravid proglottides. Scolex small, globular, not distinctly set off from neck. Suckers relatively small, ovoid, directed laterally. Neck $0.47-0.75$ long, of uniform width; minimum width $0.11-0.29$. Proglottides craspedote but velum usually short. Length/ width ratio of mature proglottides variable $(0.15-0.48$, mean 0.26 ), remains comparable in postmature proglot- 

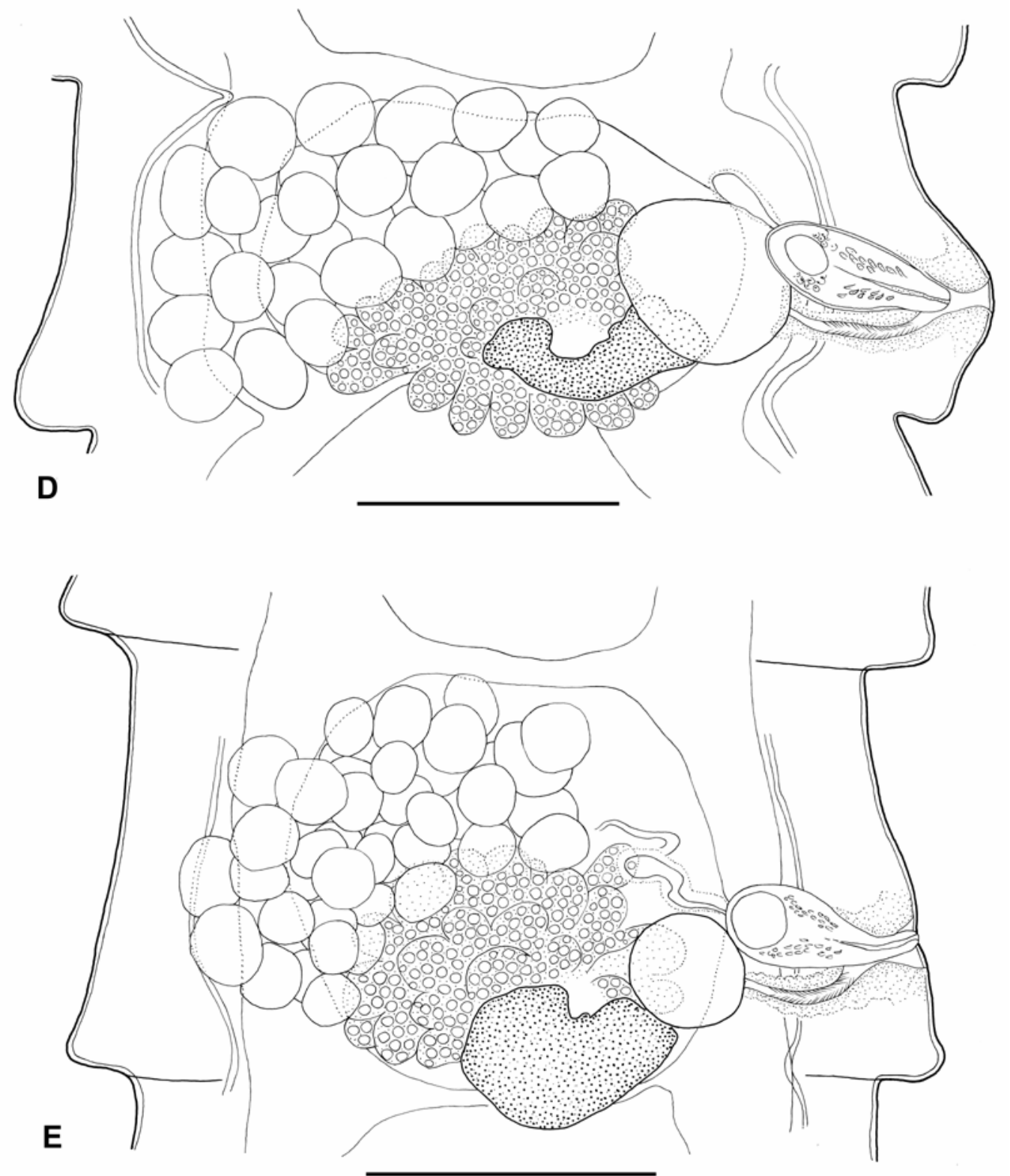

Fig. 2 D, E. Mature proglottides of Paranoplocephala bairdi from Arborimus longicaudus (D) and A. pomo (E). Scale bars = $0.30 \mathrm{~mm}$.

tides $(0.19-0.35$, mean 0.26$)$, increasing in pregravid $(0.24-0.67$, mean 0.46$)$ and gravid proglottides $(0.59$ 1.01 , mean 0.84$)$. Genital pores either unilateral or infrequently (and irregularly) alternating. In mature proglottides genital pores opening in middle of proglottis margin or slightly posteriad.

Ventral longitudinal osmoregulatory canals wide, particularly in type material. Ventral canals connected by relatively wide transverse canals. Dorsal longitudinal osmoregulatory canals $0.007-0.030$ in type material, 0.005-0.008 in other specimens, situated lateral to ventral canals. Genital ducts pass dorsally to longitudinal osmoregulatory canals.
Testes 28-51 (mean 41.1) in number, situated antiporally and anteriorly to ovary in 2-3 dorso-ventral layers. Several testes usually laterally to antiporal ventral canal; testes cross this canal dorsally (occasionally 1-3 testes found ventral to canal). Position of poral testes from level of antiporal border of vitellarium to midvitellarium, few testes usually porally to midline of proglottis. Testes overlap slightly margins of ovary, being never in contact with vitellarium. Diameter of testes 0.06-0.08. Cirrus-sac elongate or pyriform, ca. $20 \%$ of mature proglottis width; maximum size attained in postmature proglottides. Cirrus-sac wall with thin muscle layers. Proximal cirrus-sac overlaps regularly 

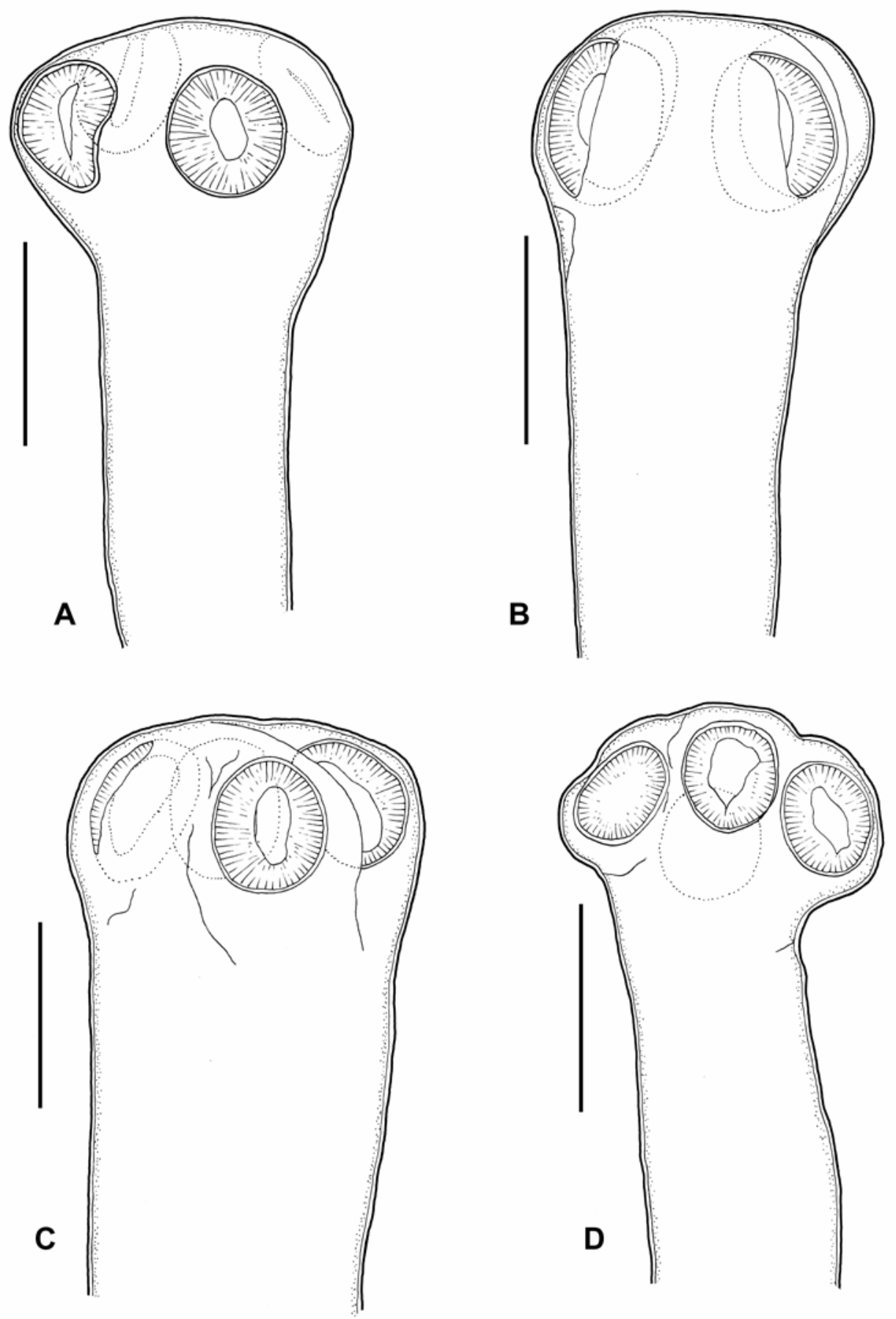

Fig. 3. Scolex and neck of Paranoplocephala bairdi from Phenacomys ungava (A - holotype), P. intermedius (B), Arborimus longicaudus (C) and A. pomo (D). Scale bars $=0.20 \mathrm{~mm}$.

poral ventral canal and sometimes extends beyond it. Ductus cirri densely armed with short spines. Internal seminal vesicle $0.035-0.110$ in mature proglottides, increasing slightly in size in postmature proglottides. External seminal vesicle relatively long and thin, irregularly looped, covered with loose cell layer.
Vagina $0.15-0.23$ (mean 0.19 ) long, on average $86 \%$ of cirrus-sac length, maximum width 0.035-0.060 (mean 0.048). Vagina slightly curved, running posteriorly to cirrus-sac and opening ventrally or posteroventrally to male pore. Internally vagina formed by distinct tube tapering proximally. Internal surface of vagina 


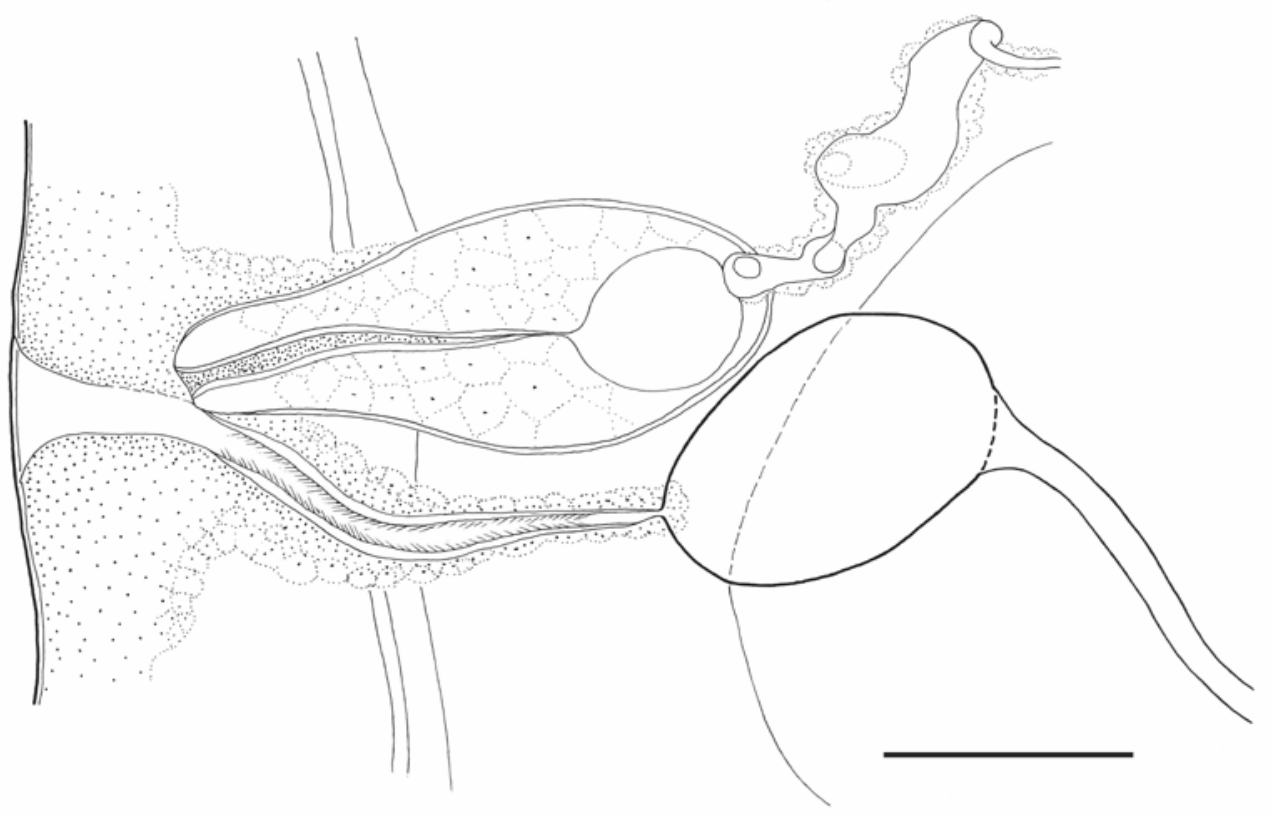

Fig. 4. Terminal genital ducts of Paranoplocephala bairdi from Phenacomys ungava (holotype). Scale bar $=0.10 \mathrm{~mm}$.

lined with fine bristles pointing distally. Vagina covered externally by thick cell layer that increases distally in width, merging with cell layer surrounding genital atrium. Seminal receptacle ovoid or circular, distinctly set off from vagina, usually partly overlapping ventral osmoregulatory canal; increases markedly in size in postmature proglottides, retaining its ovoid/circular shape. Ovary sparsely lobed, situated centrally or slightly porally, covering ca. $2 / 3$ of space between longitudinal ventral canals. Vitellarium asymmetrically bilobed or irregularly shaped, positioned porally with respect to ovary. Uterus appears ventrally in anterior proglottis as thin cell layer of reticulate appearance. Lateral parts of early uterus extend more posteriorly than central part and across ventral longitudinal canals bilaterally. In some specimens, central part of early uterus appears to be formed by transverse, anastomosing tubules. Margins of early uterus undefined. With further development central part expands posteriorly to form irregular compartments that rapidly fill with eggs; at this stage lateral parts of uterus consist of irregular, reticulated diverticula. Fully developed uterus in pregravid proglottides occupies most of medulla, with irregular anterior, posterior and lateral sacculations and complex system of internal trabeculae. Testes remain in postmature and early pregravid proglottides, overlapping developing uterus; cirrus sac, vagina and accessory organs persist in pregravid or early gravid proglottides. Eggs round in surface view, ovoid in side view. Eggs provided with pyriform apparatus, length $0.030-0.033$ (details not seen).

\section{DISCUSSION}

Although the number of Paranoplocephala specimens from the Phenacomys/Arborimus complex was too low for a proper statistical comparison (Table 2), there were some obvious metric differences between cestodes from different host species. Specifically, the specimens from $P$. ungava had wider ventral osmoregulatory canals, the specimens from $P$. intermedius had larger eggs and the specimens from $A$. pomo had more frequently alternating genital pores than the specimens from the other host species (Table 2). There were also clear differences in the length/width ratio of proglottides (Fig. 2 ). Of these variables, the pattern of genital pore alternation has been traditionally given a high taxonomic weight within Paranoplocephala. However, the relatively frequent alternation in the specimens from $A$. pomo (9-13 changes per strobila) was approached by the specimens from $P$. intermedius, among which alternation varied from unilateral to 8 changes per strobila within the same locality (Deschutes County, Oregon).

We assume that the differences mentioned above reflect intraspecific variation rather than existence of multiple species. First, most of the taxonomically important features, such as the size and structure of the scolex, number and distribution of testes, position of female glands, and dimensions and morphology of genital ducts, showed little variation among the cestode samples. Second, none of the samples was consistently different from the other samples, and the observed differences fall within the range of intraspecific variation 
Table 1. Specimens of Paranoplocephala bairdi from Phenacomys and Arborimus species used in the present analysis.

\begin{tabular}{|l|l|l|l|c|c|c|c|c|}
\hline Host species & Region & Locality & Collector & Field code & Accession number & $\mathrm{n}$ & Scolex & Eggs \\
\hline P. ungava & Quebec & Seven Islands & G.A. Schad & - & USNPC 48758 (holotype) & 1 & - & + \\
P. ungava & Quebec & Fort McKenzie & G.A. Schad & - & USNPC 48759 (paratype) & 1 & + & - \\
P. ungava & Quebec & Fort McKenzie & G.A. Schad & - & PPC $^{1}$ (paratype) & 1 & - & + \\
P. intermedius & Oregon & Deschutes Co. & C. Maser & 37190 & USNPC 95384 & 4 & + & - \\
P. intermedius & Oregon & Deschutes Co. & C. Maser & 37191 & - & 2 & - & + \\
P. intermedius & Wyoming & Moran Co. & R.L. Rausch & 2 & - & 1 & - & + \\
P. intermedius & Montana & Glacier Park & V. Walters & 11189 & - & 1 & + \\
A. longicaudus & Oregon & Coos Co. & C. Maser & 39600 & - & + \\
A. longicaudus & Oregon & Tillamook Co. & M.L. Johnson & - & USNPC 95385 & 2 & + \\
A. longicaudus & Oregon & Tillamook Co. & M.L. Johnson & 5169 & - & - \\
A. pomo & California & Sonoma Co. & M. Voge & 793 & USNPC 95386 & 1 & - \\
A. albipes & Oregon & Lane Co. & C. Maser & 40334 & USNPC 95387 & 2 & + & + \\
\hline
\end{tabular}

${ }^{1}$ Lawrence R. Penner Parasitology Collection, University of Connecticut, Storrs, USA; no accession number specified.

Table 2. Range of absolute measurements of Paranoplocephala bairdi in different species of Phenacomys and Arborimus. Maximum body width in mm, other measurements in $\mu$ m.

\begin{tabular}{|c|c|c|c|c|c|c|c|c|c|c|}
\hline & \multicolumn{2}{|c|}{ P. ungava } & \multicolumn{2}{|c|}{ P. intermedius } & \multicolumn{2}{|c|}{ A. longicaudus } & \multicolumn{2}{|c|}{ A. pomo } & \multicolumn{2}{|c|}{ A. albipes } \\
\hline & $\mathrm{n}$ & range & $\mathrm{n}$ & range & $\mathrm{n}$ & range & $\mathrm{n}$ & range & $\mathrm{n}$ & range \\
\hline Body, maximum width & 2 & $1.90-2.00$ & 6 & $1.27-2.05$ & 3 & $1.27-1.81$ & 1 & 1.25 & 1 & 1.30 \\
\hline Scolex, width & 1 & 330 & 2 & $325-335$ & 2 & $275-385$ & 1 & 315 & - & - \\
\hline Suckers, diameter & 1 & 130 & 2 & $155-160$ & 2 & $138-150$ & 1 & 108 & - & - \\
\hline Neck, length & 1 & 470 & 1 & 750 & 2 & $500-750$ & 1 & 600 & - & - \\
\hline Neck, minimum width & 1 & 150 & 1 & 160 & 2 & $105-290$ & 1 & 170 & - & - \\
\hline Ventral canals, width & 3 & $118-152$ & 6 & $40-122$ & 3 & $40-85$ & 2 & $60-82$ & 1 & 45 \\
\hline Cirrus sac, length & 3 & $215-255$ & 6 & $140-313$ & 3 & $170-220$ & 2 & $195-200$ & 1 & 150 \\
\hline Testes, number & 3 & $42-51$ & 6 & $28-45$ & 3 & $33-47$ & 2 & 44 & 1 & 41 \\
\hline Seminal receptacle, length & 3 & $125-200$ & 6 & $130-310$ & 3 & $120-210$ & 2 & $123-185$ & 1 & 120 \\
\hline Vitellarium, width & 3 & $200-270$ & 6 & $175-300$ & 3 & $106-250$ & 2 & $190-220$ & 1 & 155 \\
\hline Ovary, width & 3 & $385-502$ & 6 & $305-632$ & 3 & $206-400$ & 2 & $335-352$ & 1 & 302 \\
\hline Egg, length & 2 & $41.7-43.1$ & 2 & $47.0-57.1$ & 2 & $37.0-41.0$ & 1 & 39.8 & 1 & 44.3 \\
\hline Genital pores, alternation ${ }^{1}$ & 3 & $0-1$ & 6 & $0-8$ & 3 & 0 & 2 & $9-13$ & 1 & 1 \\
\hline
\end{tabular}

${ }^{1}$ Number of changes per strobila. 
Table 3. Mean and range (in parentheses) of absolute and relative organ measurements of Paranoplocephala spp. Values marked with an asterisk differ significantly ( $p<0.05$ ), and values in bold italics are nearly or completely non-overlapping with those of $P$. bairdi. All measurements in $\mu \mathrm{m}$.

\begin{tabular}{|c|c|c|c|c|c|c|}
\hline & $\begin{array}{c}\text { P. bairdi } \\
\mathrm{n}=14\end{array}$ & $\begin{array}{c}\text { P. arctica } \\
\mathrm{n}=6\end{array}$ & $\begin{array}{l}\text { P. fellmani } \\
\mathrm{n}=10\end{array}$ & $\begin{array}{c}\text { P. nordenskioeldi } \\
\mathrm{n}=10\end{array}$ & $\begin{array}{c}\text { P. primordialis } \\
\mathrm{n}=13\end{array}$ & $\begin{array}{c}\text { P. serrata } \\
\mathrm{n}=16\end{array}$ \\
\hline Ventral canals, width (VC) & $89.6(40-152)$ & $43.2(35-62)^{*}$ & $31.2(20-45)^{*}$ & $57.7(35-90)^{*}$ & $49.9(20-100)^{*}$ & $62.8(35-120)$ \\
\hline Cirrus sac, length (CS) & $222(150-313)$ & $228(150-340)$ & $247(173-320)$ & $241(210-285)$ & $192(130-250)$ & $287(230-390)^{*}$ \\
\hline Cirrus sac, max. length (CSM) & $283(230-350)$ & $283(250-340)$ & $325(300-360)$ & $264(220-310)$ & $230(190-290)^{*}$ & $372(280-440)^{*}$ \\
\hline Testes, distribution (TE) & $521(400-779)$ & $445(360-534)$ & $384(290-554)^{*}$ & $531(388-832)$ & $391(266-530)^{*}$ & $483(337-690)$ \\
\hline Testes, number (TN) & $41.1(28-51)$ & $60.5(49-80) *$ & $48.3(33-58)$ & $37.7(28-52)$ & $27.3(19-39)^{*}$ & $44.1(31-52)$ \\
\hline Antiporal testes, no. (ATN) & $6.2(1-10)$ & $12.2(8-16)^{*}$ & $7.3(1-12)$ & $2.6(0-6)$ & $1.4(0-4)^{*}$ & $12.3(5-21)^{*}$ \\
\hline Poral testes, no. (PTN) & $2.1(0-5)$ & $12.3(10-17)^{*}$ & $3.8(0-8)$ & $5.1(2-11)^{*}$ & $6.4(3-10) *$ & $1.0(0-5)$ \\
\hline Seminal receptacle, length (SR) & $173(120-310)$ & $191(155-260)$ & $87(60-105) *$ & $206(135-285)$ & $130(85-180)$ & $201(100-323)$ \\
\hline Seminal receptacle, max. length (SRM) & $371(255-550)$ & $438(350-570)$ & $158(120-200) *$ & $330(250-550)$ & $199(130-290)^{*}$ & $481(320-680)^{*}$ \\
\hline Vitellarium, width (VI) & $220(106-300)$ & $201(150-220)$ & $173(125-240)$ & $242(180-390)$ & $180(120-255)$ & $194(150-296)$ \\
\hline Poral distance of vitellarium (PV) & $464(350-688)$ & $352(265-470)$ & $342(270-417)$ & $471(378-690)$ & $371(278-460)$ & $476(360-610)$ \\
\hline Ovary, width (OV) & $404(206-632)$ & $312(255-386)$ & $307(196-420)$ & $431(295-640)$ & $321(145-430)$ & $416(350-635)$ \\
\hline Distance between ovary and vitellarium (DO) & $75.9(50-125)$ & $17.7(10-28)^{*}$ & $47.0(0-103)$ & $43.4(10-95)^{*}$ & $10.7(-25-35)^{*}$ & $32.8(0-77)^{*}$ \\
\hline Mature proglottides, lengtl & $0.26(0.15-0.48)$ & $0.57(0.42-0.69)^{*}$ & $0.50(0.38-0.68)^{*}$ & $0.23(0.15-0.42)$ & $0.37(0.21-0.52)^{*}$ & $0.23(0.14-0.37)$ \\
\hline Vitellarium, index of asymmetry & $0.41(0.39-0.48)$ & $0.48(0.45-0.52)^{*}$ & $0.43(0.37-0.50)$ & $0.47(0.38-0.54)^{*}$ & $0.49(0.43-0.55)^{*}$ & $0.43(0.37-0.50)$ \\
\hline
\end{tabular}

Table 4. Mean and range of external dimensions and egg length of Paranoplocephala spp. Values marked with an asterisk differ significantly ( $p<0.05$ ), and values in bold italics are nearly or completely non-overlapping with those of $P$. bairdi. Maximum body width in $\mathrm{mm}$, other measurements in $\mu \mathrm{m}$.

\begin{tabular}{|c|c|c|c|c|c|c|c|c|c|c|c|c|c|c|c|c|c|c|}
\hline & \multicolumn{3}{|c|}{ P. bairdi } & \multicolumn{3}{|c|}{$P$. arctica } & \multicolumn{3}{|c|}{ P. fellmani } & \multicolumn{3}{|c|}{ P. nordenskioeldi } & \multicolumn{3}{|c|}{ P. primordialis } & \multicolumn{3}{|c|}{ P. serrata } \\
\hline & $\mathrm{n}$ & mean & range & $\mathrm{n}$ & mean & range & $\mathrm{n}$ & mean & range & $\mathrm{n}$ & mean & range & $\mathrm{n}$ & mean & range & $\mathrm{n}$ & mean & range \\
\hline Body, max. width & 12 & 1.56 & $1.25-2.05$ & 6 & 1.90 & $1.28-2.85$ & 7 & 1.49 & $1.27-1.71$ & 10 & 1.92 & $1.40-2.87$ & 10 & 1.36 & $0.75-2.05$ & 14 & 2.65 & $2.05-3.35^{*}$ \\
\hline Scolex, width & 6 & 328 & $275-385$ & 5 & 288 & $215-335$ & 10 & 455 & $400-530^{*}$ & 6 & 443 & $370-610^{*}$ & 10 & 490 & $430-560 *$ & 15 & 355 & $260-430$ \\
\hline ameter & 6 & 140 & $108-160$ & 5 & 142 & $105-165$ & 10 & 197 & $170-235^{*}$ & 6 & 208 & $175-250^{*}$ & 10 & 189 & $153-225^{*}$ & 15 & 167 & 00 \\
\hline Neck, 1 & 5 & 614 & $470-750$ & - & - & - & 5 & 448 & $170-850$ & 3 & 357 & $270-450$ & 7 & 593 & $300-1,000$ & 13 & 549 & $140-1,100$ \\
\hline Neck, min. width & 5 & 175 & $105-290$ & 4 & 104 & $80-125$ & 6 & 196 & $130-270$ & 4 & 116 & $90-150$ & 9 & 219 & $125-300$ & 14 & 146 & $70-270$ \\
\hline Egg, length & 7 & 41.9 & $37-47$ & 6 & 66.8 & $64-69 *$ & 7 & 43.9 & $39-46$ & 9 & 50.7 & $47-55^{*}$ & 11 & 48.9 & $41-66^{*}$ & 14 & 60.4 & $55-69 *$ \\
\hline
\end{tabular}


normally seen within Paranoplocephala spp. In addition, the multivariate analyses suggest that the specimens from Phenacomys and Arborimus represent a relatively uniform group of cestodes that is morphometrically distinct from the other, related species of Paranoplocephala. Paranoplocephala bairdi, P. nordenskioeldi and $P$. serrata resemble each other in many respects, including the uterine development. The structure of the early uterus in these three species fully corresponds to that of $P$. omphalodes, the type species of Paranoplocephala (cf. Rausch 1976, Genov et al. 1996), but the uterine development of $P$. arctica (Haukisalmi et al. 2001), P. fellmani (Haukisalmi and Henttonen 2001) and, possibly, $P$. primordialis (Douthitt 1915) represents other subtypes recognized within Paranoplocephala. However, none of the species considered here, including $P$. bairdi, belongs to Paranoplocephala sensu stricto, as defined by Haukisalmi and Henttonen (2003), mainly because of differences in the morphology of the scolex, suckers and genital ducts.

Despite the apparent similarity between $P$. bairdi, $P$. nordenskioeldi and $P$. serrata, they remained largely separate in the discriminant analysis and showed several statistically significant differences, including diagnostic, non-overlapping features. Egg length seems to be the most clear-cut individual feature separating these three species. In addition to the quantitative differences considered in this analysis, $P$. nordenskioeldi and $P$. serrata differ from $P$. bairdi with respect to the structure of the scolex and genital ducts (Haukisalmi and Henttonen 2000, Haukisalmi et al. 2001). The classification success of $P$. bairdi in the discriminant analysis was not perfect $(78.6 \%)$, but it still exceeded $P$. nordenskioeldi $(60 \%)$ in this respect; the independent status of the latter species has been confirmed by molecular methods (Haukisalmi et al. 2001). In a methodologically comparable morphometric analysis of $P$. omphalodes-like species, the classification success varied between $80-90 \%$, also suggesting that occasional misclassifications do occur even among biologically valid anoplocephaline species defined by molecular methods (Haukisalmi et al. 2004).

Paranoplocephala bairdi also resembles Paranoplocephala montana (Kirshenblat, 1941), described from Microtus arvalis (Pallas) and Chionomys nivalis (Martins) from Caucasus (Georgia and Armenia), but they can be reliably separated by the length of the strobila (much longer in P.b.), shape of the seminal receptacle (elongate or pyriform in P.m.), width of the ventral longitudinal canals (wider in P.b.) and other quantitative features. Kirshenblat (1941) did not designate a type specimen for $P$. montana, and new material is needed to define more precisely the morphology and intraspecific variation of this poorly known species.

Thus, the combined evidence from uni- and multivariate morphometrics and qualitative comparisons suggest that all available specimens of Paranoplocephala from Phenacomys and Arborimus represent a single species, i.e. $P$. bairdi. Since there are no reports or descriptions of $P$. bairdi-like cestodes from other species of voles and lemmings, we consider $P$. bairdi a hostspecialist species of heather voles and tree voles with a wide geographical distribution in North America. Paranoplocephala bairdi is so far the only cestode species in Phenacomys and Arborimus whose identity has been confirmed by comparative morphological analysis (below).

Other Paranoplocephala species reported from Phenacomys are P. communis (Douthitt, 1915) (see Lubinsky 1957) and P. primordialis (see Rausch and Schiller 1949, Rausch 1952, Kinsella 1967). Lubinsky (1957) also mentioned P. variabilis (Douthitt, 1915) as a parasite of Phenacomys, but this species is presently assigned to Anoplocephaloides Baer, 1923 (see Rausch 1976).

Paranoplocephala communis is usually considered a synonym of $P$. primordialis (see Baer 1927, Rausch and Schiller 1949, Spasskii 1951) or species inquirenda (Tenora et al. 1986), although Tenora (1996) described specimens from North American Clethrionomys spp. under the former name. The original description of $P$. communis is based on contracted, sectioned fragments and its taxonomical status remains obscure. The presence of $P$. primordialis in Phenacomys can not be verified due to the lack of descriptions, and it is possible that some of the existing reports actually concerned $P$. bairdi.

Finally, the present analysis emphasises the need to apply a wide range of morphometric characters and multivariate statistical analyses to discriminate species within the large and morphologically relatively uniform genus Paranoplocephala (see also Haukisalmi et al. 2004).

Acknowledgements. We wish to thank Joseph A. Cook and Eric P. Hoberg for support and access to the cestode materials collected during the Beringian Coevolution Project (see Hoberg et al. 2003). Our research on anoplocephalid cestodes of rodents in the Holarctic region, conducted at the Finnish Forest Research Institute, has been primarily funded by the Academy of Finland (Research Council for the Biosciences and Environment, project no. 40813). 


\section{REFERENCES}

BAER J.G. 1927: Monographie des cestodes de la famille des Anoplocephalidae. Bull. Biol. Fr. Belg. (Suppl.) 10: 1241.

BELLINGER M.R., HAIG S.M., FORSMAN E.D., MULLINS T.D. 2005: Taxonomic relationships among Phenacomys voles as inferred by cytochrome $b$. J. Mammal. 86: 201-210.

DOUTHITT H. 1915: Studies on the cestode family Anoplocephalidae. Ill. Biol. Monogr. 1: 1-96.

DURETTE-DESSET M.-C., KINSELLA J.M., FORRESTER D.J. 1972: Arguments en faveur de la double origine des Nématodes néarctiques du genre Heligmosomoides Hall, 1916. Ann. Parasitol. Hum. Comp. 47: 365-382.

GENOV T., VASILEVA G.P., GEORGIEV B.B. 1996: Paranoplocephala aquatica $\mathrm{n}$. sp. (Cestoda, Anoplocephalidae) from Arvicola terrestris and Ondatra zibethica (Rodentia), with redescriptions and comments on related species. Syst. Parasitol. 34: 135-152.

HAUKISALMI V., HENTTONEN H. 2000: Description and morphometric variability of Paranoplocephala serrata $n$. sp. (Cestoda: Anoplocephalidae) in collared lemmings (Dicrostonyx spp., Arvicolinae) from Arctic Siberia and North America. Syst. Parasitol. 45: 219-231.

HAUKISALMI V., HENTTONEN H. 2001: Biogeography of helminth parasitism in Lemmus Link (Arvicolinae), with the description of Paranoplocephala fellmani n. sp. (Cestoda: Anoplocephalidae) from the Norwegian lemming $L$. lemmus (Linnaeus). Syst. Parasitol. 49: 7-22.

HAUKISALMI V., HENTTONEN H. 2003: What is Paranoplocephala macrocephala (Douthitt, 1915) (Cestoda: Anoplocephalidae)? Syst. Parasitol. 54: 53-69.

HAUKISALMI V., HENTTONEN H., NIEMIMAA J., RAUSCH R.L. 2002: Description of Paranoplocephala etholeni n. sp. (Cestoda: Anoplocephalidae) in the meadow vole Microtus pennsylvanicus, with a synopsis of Paranoplocephala s.l. in Holarctic rodents. Parasite 9: 305-314.

HAUKISALMI V., WICKSTRÖM L.M., HANTULA J., HENTTONEN H. 2001: Taxonomy, genetic differentiation and Holarctic biogeography of Paranoplocephala spp. (Cestoda: Anoplocephalidae) in collared lemmings (Dicrostonyx; Arvicolinae). Biol. J. Linn. Soc. 74: 171196.

HAUKISALMI V., WICKSTRÖM L.M., HENTTONEN H., HANTULA J., GUBÁNYI A. 2004: Molecular and morphological evidence for multiple species within Paranoplocephala omphalodes (Cestoda, Anoplocephalidae) in Microtus voles (Arvicolinae). Zool. Scr. 33: 277-290.

HOBERG E.P., KUTZ S.J., GALBREATH K.E., COOK J.A. 2003: Arctic biodiversity: from discovery to faunal baselines - revealing the history of a dynamic ecosystem. J. Parasitol. 89 (Suppl.): S84-S95.

KINSELLA J.M. 1967: Helminths of Microtinae in western Montana. Can. J. Zool. 45: 269-274.
KIRSHENBLAT Y.D. 1941: A new tepeworm from Transcaucasian voles. Soobsch. Akad. Nauk GrSSR 2: 273-276. (In Russian.)

LUBINSKY G. 1957: List of helminths from Alberta rodents. Can. J. Zool. 35: 623-627.

MUSSER G.G., CARLETON M.D. 1993: Family Muridae. In: D.E. Wilson and D.M. Reeder (Eds.), Mammal Species of the World. Smithsonian Institution Press, in association with the American Society of Mammalogists, Washington and London, pp. 501-755.

PETERSON R.L. 1962: Notes on the distribution of Microtus chrotorrhinus. J. Mammal. 43: 420.

RAUSCH R.L. 1952: Studies on the helminth fauna of Alaska. XI. Helminth parasites of microtine rodents - taxonomic considerations. J. Parasitol. 38: 415-444.

RAUSCH R.L. 1976: The genera Paranoplocephala Lühe, 1910 and Anoplocephaloides Baer, 1923 (Cestoda: Anoplocephalidae), with particular reference to species in rodents. Ann. Parasitol. Hum. Comp. 51: 513-562.

RAUSCH R.L., RAUSCH V.R. 1973: Heligmosomoides johnsoni sp. nov. (Nematoda: Heligmosomatidae) from the heather vole, Phenacomys intermedius Merriam. Can. J. Zool. 51: 1243-1247.

RAUSCH R.L., SCHILLER E.L. 1949: A critical study of North American cestodes of the genus Andrya with special reference to A. macrocephala Douthitt, 1915 (Cestoda: Anoplocephalidae). J. Parasitol. 35: 306-314.

SCHAD G.A. 1954: Helminth parasites of mice in northeastern Quebec and the coast of Labrador. Can. J. Zool. 32: 215-224.

SPASSKII A.A. 1951: [Anoplocephalate tapeworms of domestic and wild animals.] The Academy of Sciences of the USSR, Moscow, $783 \mathrm{pp}$.

TENORA F. 1996: Andrya communis Douthitt, 1915 (Anoplocephalidae), a parasite of Clethrionomys spp. (Arvicolidae) in the Nearctic region. Helminthologia 33: 37-41.

TENORA F., MURAI É., VAUCHER C. 1986: On Andrya Railliet, 1893 and Paranoplocephala Lühe, 1910 (Cestoda, Monieziinae). Parasitol. Hung. 19: 43-75.

VERTS B.J., CARRAWAY L.N. 1998: Land Mammals of Oregon. University of California Press, Berkeley and Los Angeles, 668 pp.

WICKSTRÖM L.M., HAUKISALMI V., VARIS S., HANTULA J., HENTTONEN H. 2005: Molecular phylogeny and systematics of anoplocephaline cestodes in rodents and lagomorphs. Syst. Parasitol. (in press).

WILSON D.E., RUFF S. (Eds.) 1999: The Smithsonian Book of North American Mammals. Smithsonian Institution Press, in association with the American Society of Mammalogists, Washington and London, $750 \mathrm{pp}$.

VOGE M. 1955: A list of cestode parasites from California mammals. Am. Midl. Nat. 54: 413-417. 